\title{
TRANSLATION FORM OF DEPOT FAT IN STARVATION
}

\author{
YASUMASA MAJIMA \\ Institute of Nutrition, School of Medicine, \\ Keio University, Tokyo, Japan
}

(Received for publication September 28, 1970)

\section{INTRODUCTION}

Gordon et $a l^{1-3}$ suggested that the transport of depot fat to the site of utilization probably takes place in the form of free fatty acid (unesterified fatty acid).

Under both normal and abnormal circumstances, the amount of free fatty acid is very small in the serum and liver occupying only $1 / 4 \sim 1 / 5$ of triglyceride or phospholipid. The portion derived from dietary fat is transported mainly in the lymph and then in the blood in the form of triglyceride (chylomicron) to be deposited as it is.

We have therefore used fasting albino rats to measure triglyceride and free fatty acid in the serum and liver, suggesting thereby the transport of depot fatty acid in the form of triglyceride instead of free fatty aid. ${ }^{4}$

Further experiments have revealed the occurrence of transportation in the form of a low density lipoprotein, as reported below.

\section{EXPERIMENT}

Male albino rats of approximately $200 \mathrm{mg}$ were maintained on the following basic diet for 3 weeks and fasted for 48 hours, receiving water alone. One sample consisted of materials obtained from 15 rats and 3 samples made up 1 group. Each lipoprotein in the serum was separated by an ultracentrifugal method $^{5}$ and each fat in the lipoprotein was isolated by the method of the author. ${ }^{6}$ After adding an adequate amount of $\mathrm{NaCl}$ and $\mathrm{NaBr}$ to serum, a low density lipoprotein with $\mathrm{d}<1.019$ was separated at $40,000 \mathrm{rpm}$ for 22 hours, a low density lipoprotein with $d=1.019-1.063$ was centrifuged at $40,000 \times \mathrm{g}$ 
for 22 hours, and a high density lipoprotein with $\mathrm{d}=1.063-1.21$ and $\mathrm{d}>1.21$ at $40,000 \times \mathrm{g}$ for 48 hours. Each lipoprotein was further subjected to mild extraction with methanol : ether $(3: 1)$, followed by chromatography on silicic acid and then alumina, to separate the fractions of cholesterolester, triglyceride, diglyceride, monoglyceride, free fatty acid, free cholesterol and phospholipid. Fatty acids in triglyceride and depot fat were analyzed by gas chromatography. ${ }^{7}$

Basic Diet

\begin{tabular}{l|r|l|r}
\hline \hline Casein* & $14 \mathrm{~g}$ & $\alpha$. Tocopherol & $2 \mathrm{mg}$ \\
Starch & $36 \mathrm{~g}$ & $\mathrm{~B}_{12}$ & $0.002 \mathrm{mg}$ \\
Sucrose & $36 \mathrm{~g}$ & Niacin & $20 \mathrm{mg}$ \\
M. Salt & $4 \mathrm{~g}$ & Thiamin-HCl & $2 \mathrm{mg}$ \\
Olive oil & $10 \mathrm{~g}$ & $\mathrm{~B}_{2}$ & $3 \mathrm{mg}$ \\
$\mathrm{A}$ & $3,000 \mathrm{I} . \mathrm{U}$. & Pyridoxine & $3 \mathrm{mg}$ \\
$\mathrm{D}_{3}$ & $400 \mathrm{I} . \mathrm{U}$. & Pantothenic acid & $1 \mathrm{mg}$ \\
Ascorbic acid & $75 \mathrm{mg}$ & $\mathrm{K}$ & $0.4 \mathrm{mg}$ \\
Choline HCl & $100 \mathrm{mg}$ & & \\
\hline
\end{tabular}

(* washing with mild methanol and ether)

\section{RESULTS AND DISCUSSION}

The serum total fat in adult albino rats reached a maximum within $2 \sim 3$ days after fasting. ${ }^{4}$ The determination was therefore carried out within 48 hours of fasting. Table 1 summarizes the amount of each fat in serum lipoprotein in albino rats maintained on a constant basic diet for 3 weeks and fasted for 48 hours in comparison with controls before fasting (normal).

At 48 hours of fasting, as compared with the pre-fasting state, triglyceride in the low density lipoprotein with $d<1.019$ increased by about 1.6 times, occupying about $54 \%$ of this lipoprotein. The increase in other fractions was minimal. Table 2 summarizes the results of comparison between the amount of each fatty acid in the triglyceride in low density lipoprotein with $\mathrm{d}<1.019$ and that in depot fat before fasting.

In both groups, $\mathrm{C}_{18}: 1$ was found to be the most abundant followed by $\mathrm{C}_{16}: 0$, while the amount of $\mathrm{C}_{14}: 0, \mathrm{C}_{12}: 0, \mathrm{C}_{10}: 0, \mathrm{C}_{18}: 2, \mathrm{C}_{18}: 3$, and $\mathrm{C}_{20}: 4$ was small, giving a rather similar fatty acid composition.

These results appeared to indicate that the triglyceride in the low density lipoprotein $(d<1.019)$ which increased in the serum upon fasting was probably derived from depot fat. 


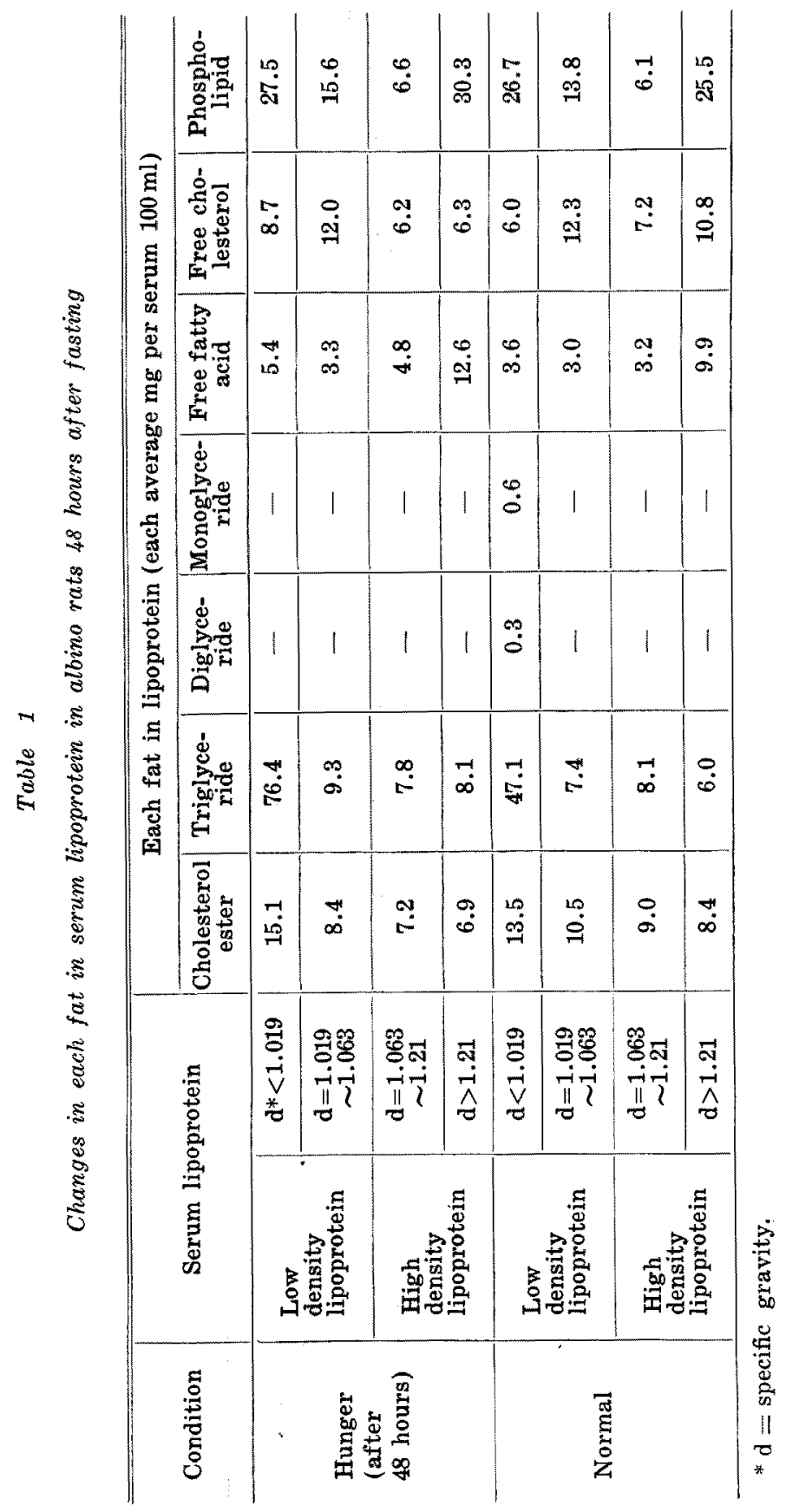




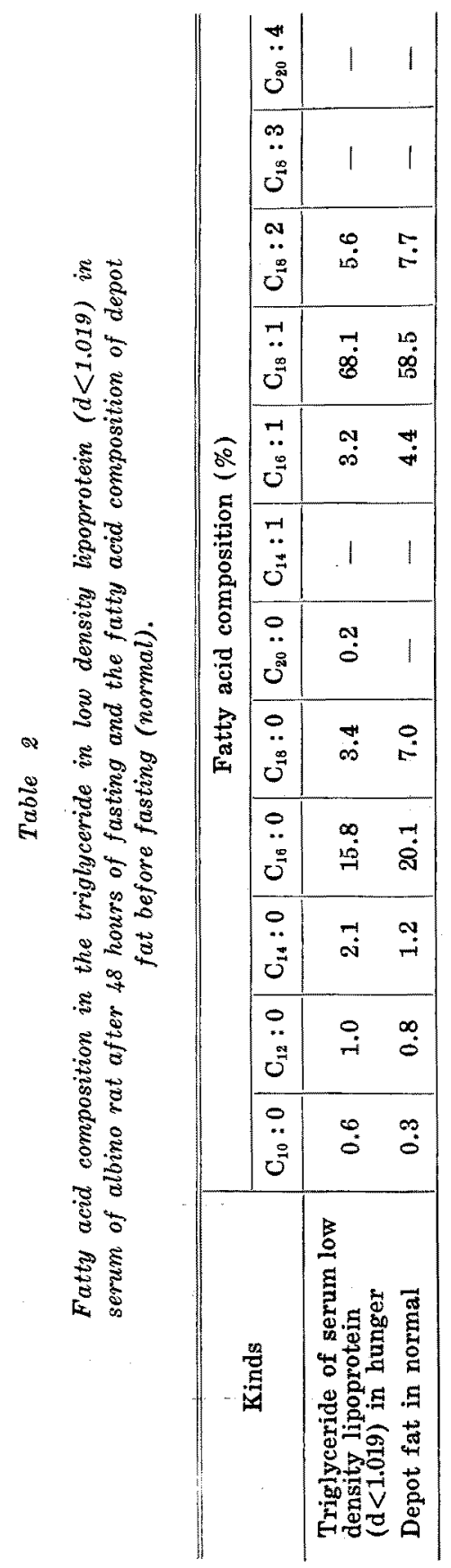


The transport of depot fat upon fasting thus appears to take place not in the form of free fatty acid but in the form a low density lipoprotein mainly triglyceride.

\section{SUMMARY}

Albino rats were maintained on a constant basic diet and fasted for 48 hours, to determine each lipid in serum lipoprotein for comparison with the value before fasting.

As the result, triglyceride in low density lipoprotein appeared to have increased as compared with the prefasting level. Other fats increased only slightly. The fatty acid composition of the increased triglyceride was relatively quite similar to that of depot fat before fasting.

The depot fat thus appeared to be transported during fasting, not in the form of free fatty acid but in the form of a low density lipoprotein, mainly triglyceride.

\section{REFERENCES}

1. Gordon, R.S. and Cherkes, A. (1956) Unesterified fatty acid in human blood plasma. J. clin. Invest. 35: 206.

2. Gordon, R.S. and Bragdon, J.H. (1958) Tissue distribution of $\mathrm{C}^{14}$ after the intravenous injection of labeled chylomicrons and unesterified fatty acids in the rat. J. clin. Invest. $37: 574$.

3. Gordon, R.S. and Cherkes, A. (1957) Unesterified fatty acid in human blood plasma. J. clin. Invest. $36: 810$.

4. Majima, Y. and Kurata, C. (1966) Translation of depot fat in starvation. J. Jap. Soc. Food Nutrition 18: 374. (in Japanese)

5. Gofman, J.W., Lindgren, F.T. and Elliot, H.A. (1949) Ultracentrifugal studies of lipoproteins of human serum. J. Biol. Chem. 179: 973.

6. Majima, Y. and Kurihara, F. (1963) Separation and determination of fat. J. Jap. Soc. Food Nutrition 16: 280. (in Japanese)

7. James, A.T. and Martin, A.T. (1952) Gaschromatography. Analyst 77: 915. 